\title{
Business Model Innovation vs. Business Model Inertia: the Role of Disruptive Technologies
}

\author{
Stefan Vorbach ${ }^{1}$, Harald Wipfler ${ }^{1}$, and Sven Schimpf ${ }^{2}$ \\ ${ }^{1}$ Institute of General Management and Organization, Graz University of Technology, Graz, Austria \\ ${ }^{2}$ Competence Centre R\&D Management, Fraunhofer IAO/IAT University of Stuttgart, Stuttgart, Germany
}

Received June 30, 2017; accepted July 13, 2017; published online August 17, 2017

\begin{abstract}
This contribution addresses the impact of disruptive technologies on business model innovation. While such technologies have the potential to significantly alter the way in which businesses operate, business model inertia hinders companies from adopting the new technological possibilities. Little research has focused on the difficulties incumbents face when innovating their business models. By reviewing current literature on business model innovation, this paper summarizes challenges companies face when dealing with potential disruptive technologies and creating viable business models.
\end{abstract}

Keywords: Business Model, Business Model Innovation, Potential Disruptive Technology, Business Model Inertia

Innovation vs. Beharrungsvermögen von Geschäftsmodellen: Die Rolle disruptiver Technologien

Zusammenfassung: Dieser Beitrag diskutiert den Einfluss disruptiver Technologien auf die Innovation von Geschäftsmodellen. Während diese Technologien das Potential für substantielle Veränderungen von bestehenden Geschäftsmodellen haben, können Unternehmen durch das Beharrungsvermögen ihrer Geschäftsmodelle auch darin behindert werden, die neuen technologischen Entwicklungen aufzugreifen. Bislang befassen sich noch wenige Arbeiten mit der Frage, wodurch etablierte Unternehmen bei der Innovation ihrer Geschäftsmodelle behindert werden. Basierend auf aktueller Literatur zu Geschäftsmodellinnovation beschreibt dieser Beitrag, in welchem Spannungsfeld aus potentiell disruptiven Technologien und der möglichen Entwicklung rentabler Geschäftsmodelle Unternehmen stehen.

\footnotetext{
S. Vorbach $(\square)$

Institute of General Management and Organization,

Graz University of Technology,

Kopernikusgasse 24,

8010 Graz, Austria

stefan.vorbach@tugraz.at
}

Schlüsselwörter: Geschäftsmodell, Geschäftsmodellinnovation, Potenziell disruptive Technologie, Beharrungsvermögen von Geschäftsmodellen

\section{Introduction}

Technological innovations increasingly impact the transformation of business models (BM) [1]. Disruptive technological developments significantly influence business environments and alter the way in which businesses are operated. These technologies replace existing technologies of incumbents by sacrificing features that are important to current customers and offering different attributes [2] and change the performance metrics along which firms compete [3]. It is therefore important to understand how disruptive technologies drive business model innovation (BMI) and which difficulties incumbents face when adopting new technological options. This paper discusses the impact of disruptive technologies on BMI and the factors that hinder the adoption of new technological developments.

The remainder of the paper is structured as follows: Sect. 2 describes the conception of potential disruptive technologies. Sect. 3 explains the innovation of BMs with respect to new technologies, and Sect. 4 discusses different causes of business model inertia, followed by the conclusion of the paper.

\section{Potentially Disruptive Technologies}

Christensen [4] first introduced the term "disruptive technology" to refer to a new technology having lower cost and performance measured by traditional criteria, but having higher ancillary performance. Christensen [4] suggested that disruptive technologies may enter and expand emerging market niches, improve over time, and ultimately attack established products in their traditional markets. Poten- 


\begin{tabular}{|ll|}
\hline $\begin{array}{l}\text { TABLE 1 } \\
\text { Characteristics of potentially disruptive technologies }\end{array}$ \\
\hline $\begin{array}{l}\text { Fulfilment of a basic set } \\
\text { of user requirements }\end{array}$ & $\begin{array}{l}\text { The starting point of potentially disruptive technological innovations is located most often at the } \\
\text { low end of the market by means of functionalities provided. These are different from incumbents' } \\
\text { solutions through the provision of only a basic set of functionalities matching most important } \\
\text { user requirements }\end{array}$ \\
\hline $\begin{array}{l}\text { Overall potential for } \\
\text { further development }\end{array}$ & $\begin{array}{l}\text { In technology life-cycle models, potentially disruptive technologies are often immature or under- } \\
\text { performing but able to substitute solutions currently applied when further developed }\end{array}$ \\
\hline $\begin{array}{l}\text { Low cost compared to } \\
\text { incumbents' solutions }\end{array}$ & $\begin{array}{l}\text { Potentially disruptive solutions most often compete through lower cost in incumbents' markets, } \\
\text { combined with a reduced and more focused fulfilment of a basic set of requirements }\end{array}$ \\
\hline $\begin{array}{l}\text { Overcompliance of user } \\
\text { requirements by incum- } \\
\text { bents' solutions }\end{array}$ & $\begin{array}{l}\text { In contrast to the indicator of fulfilling a basic set of functionalities, overcompliance of customer } \\
\text { requirements is related to performance features that are addressing the high-end of the market. } \\
\text { These performance features are often linked to high margins and are therefore of great interest } \\
\text { for incumbents }\end{array}$ \\
\hline
\end{tabular}

tially disruptive technologies are characterized as shown in Table $1[5]$ :

Some criticism on Christensen's concept has been raised recently: First, not all the disruptive technologies follow the path of "attack from below" [6] and enter the market from the low-end. Second, not all the incumbents experience failure in launching a disruptive technology. While incumbents may be better positioned to take advantage of new technologies (superior resources, R\&D capability and complementary assets), Sood and Tellis [7] argued that potentially disruptive technologies are introduced as frequently by incumbents as by new entrants. Third, one of the main claims of Christensen is that disruptive technology is often associated with replacing the incumbent firm's market leadership. However, an entrant strategy of initially competing followed by later cooperating would suggest that, in some cases of disruptive technology, old technology will be totally replaced, while incumbents' market leadership might still be preserved. Nonetheless, established investments of the incumbents generally are rendered obsolete [3].

We propose an extended concept of disruptive technology adapted from Christensen's theory. Thus, a disruptive technology is an emerging technology following a different technological trajectory from existing technology. It has higher ancillary performance, which can create niche/fringe markets initially and finally be dominant in unexpected application areas. Disruptive technology, therefore, will often bring great challenges to incumbents because it changes the profit models and existing value networks of firms.

\section{Business Model Innovation}

In order to gain a differentiated competitive advantage, technological innovation often goes along with $\mathrm{BMI}$, which may also lead to the creation of a new industry [8]. In this way, the BM itself starts to become an object for innovation. BMI can be defined as changes in business logic that are new to the focal firm, yet not necessarily new to the world, and that result in observable changes in the practice of the firm. BMI typically involves changes in multiple BM components as it alters the business logic as a whole [9]. Examples include sharing economy based on platform models or service bundling.
Increasingly, the literature has been moving from conceptualizing, characterizing, and explaining a BM at a given point in time towards a more dynamic view that examines phenomena like BMI and adaptation [10]. Adaptation may imply changes of the firm's value proposition, market segment, value chain and value-capture, or how these are linked in an architecture.

The difference between a pre-existing BM and a new one has also been highlighted by Velu [11]: the more radical the change in the BM component is, the more radical is the resulting BM. Cavalcante et al. [12] adopted a process-based conceptualization of BM and have identified four main typologies of business model change (i.e. BM creation, BM extension, BM revision, and BM termination), which they then linked to the degree of BMI.

The process of $\mathrm{BMI}$ is often a learning process in which discovery through experimentation is more appropriate than conventional analytical approaches [13]. Chesbrough [14] argues BMI experimentation can help overcome barriers to BM change. Due to the complexity of the commercialization of emerging technology based ventures, it is conceivable that the firms will go through many cycles of design of their business model within the entire innovation process. As recently suggested by Lubik and Garnsey [15], and before by Sosna et al. [16], emerging-technologybased ventures will most likely go through a 'trial-anderror' process of learning to build their BM. Therefore, these companies will encounter many trigger points that will start constant cycles of adjustments.

\section{Business Model Inertia}

The reconfiguration of BMs is associated with many difficulties which need to be overcome, such as (1) identifying change needs, (2) overcoming inertia, (3) accepting new structures and choosing adequate approaches to renovation [17]. Given organizational inertia and outcome uncertainty, firms are unlikely to change their BM unless they have relatively strong incentives to do so. Even in cases where the need for adaptation seems evident, the firm's strategic orientation and the associated path dependencies are likely to impede the process of adapting an existing BM to new market demands or competitive threats [10]. 
Business models as cognitive patterns

BMs represent mental patterns.

- Established companies tend to derive dominant logic from extant BM [19] and fit new technologies to the traditional patterns [20].

- Incumbents prefer to stay close to existing BMs, focusing on efficiency and economies of scale and scope and are thus cognitively constrained in finding new ways for value creation [21].

- Cognitive restrictions also hinder enterprises from recognizing potential strategic choices.

- Even if a company recognizes alternatives as potential choices, it might reject them for normative reasons as not being suitable for the organization [22].

\section{Unclear business \\ models for first movers}



Path-dependent evolvement of business models

- Dominant BM logics,

complementary assets (e.g.

bundling of products and services)

and contingent events (e.g. critical

incidents, regulatory changes) may

cause an unintended path-

dependent development of the

company's BM [21].

- The path-dependent process leads to a lock-in situation, restricting the company to the resulting BM and limiting the enterprises range of technological options.

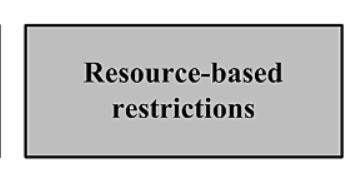

- Self-reinforcing

mechanisms align

resources to specific

environmental

conditions.

- The existing resource

base is then no longer

sufficient to realize

alternatives, which are required due to the new technological options [22].

\section{Business Model Inertia}

Fig. 1: Causes for business model inertia

New technological developments are drivers for BM change. Novel technologies, which may also come from other sectors such as IT and digitalization [1], offer new possibilities to organize the different elements of a BM, thus allowing for BMI. On the other hand, modifications of existing BMs may be required in order to be able to successfully apply and exploit the new technologies. Main challenges in developing new BMs are therefore managing the complexity of the upcoming disruptive technologies and anticipating the business logics in nascent markets [18].

In literature [19-22], different causes for BM inertia are discussed (see Fig. 1):

1. Business models as cognitive patterns

2. Unclear business models for first-movers

3. Path-dependent evolvement of business models

4. Resource-based restrictions

\section{Discussion and Conclusion}

Throughout history, successful firms have often experimented with new technologies to forestall their replacement by new firms. When technological discontinuities are introduced into an existing industry, they confront an existing industrial organization, established market relationships, specifically developed assets, and stable and predictable collaboration patterns. Scholars have argued that technological discontinuities lead to industry shakeouts that can nullify the competitive advantage of an incumbent [23]. However, technological discontinuities do not change dominant industry logics until they begin to usher in different BM that modify asset specificities, create new dependency ties, and reshape collaboration patterns. Even if a potentially disruptive technology is involved, as long as it can be integrated within the existing industry value chain, it will not alter the balance of power between its actors or its established appropriation modes. But when one of these components is affected, dominant industry logics may be challenged.

Sabatier et al. [23] found concrete examples of disruptive BMs in the biotech sector that build on technological discontinuities and "change the 'old' ways in which value has been created and captured" along the value chain in the drug industry. Yet, such BMI may take time as a number of interacting factors come into play: The disruptive nature of new technologies does not automatically change an industry's dominant logic - the challenge comes later when BMs evolve and when small firms can ally with other actors, either new or already existing, that promote a different set of complementary assets [23]. In other words, while entrepreneurs must flesh out a business model in order to develop and bring a new technology to the market, the novelty of the technology itself may not automatically call for the development of an innovative BM, e.g. act as an enabler. Other actors and industry-level processes are likely to be involved in BMI. Further, entrepreneurial firms have the advantage to be less hindered by path dependencies and cognitive constraints to fit new technologies into existing BMs [21].

Several scholars have emphasized that problems of technology shifts and radical technological change are often related to BM inertia. As concluded by Christensen [24], the fundamental challenge of disruptive technologies is "a 
business model problem, not a technology problem", meaning that the key challenge of technology shifts lies in the interaction between technological development and BMI [25, 26]. However, while a new BM can be crucial to commercializing and capturing the value of a technological innovation $[8,14,19]$, an existing BM can also constitute a lock-in that hinders technology shifts [20].

In such situations, the technology shift becomes a BM problem. Technologies are not disruptive per se, but companies may fail to create viable $B M s$ to incorporate the new technologies [27]. A lock-in to an existing BM hinders companies from picking up new technological opportunities and adapting to technological change [28].

Acknowledgements. Open access funding provided by Graz University of Technology.

Open Access This article is distributed under the terms of the Creative Commons Attribution 4.0 International License (http://creativecommons. org/licenses/by/4.0/), which permits unrestricted use, distribution, and reproduction in any medium, provided you give appropriate credit to the original author(s) and the source, provide a link to the Creative Commons license, and indicate if changes were made.

\section{References}

1. Baden-Fuller, C.; Haefliger, S.: Business Models and Technological Innovation, Long Range Planning, 46 (2013), no 6, pp 419-426

2. Bower, J. L.; Christensen, C. M.: Disruptive Technologies: Catching the Wave. Harvard Business Review, 73 (1995), no 1, pp 43-53

3. Danneels, E.: Disruptive Technology Reconsidered: A Critique and Research Agenda, Journal of Product Innovation Management, 21 (2004), no 4, pp 246-258

4. Christensen, C. M.: The Innovator's Dilemma. When New Technologies Cause Great Firms to Fail. Boston, MA: Harvard Business School Press, 1997

5. Schimpf, S.: Crowdsourcing, Digitisation and Acceleration: Is Corporate R\&D Disrupting Itself?, R\&D Management Conference 2016, Cambridge, 3-6 July 2016, 2016

6. Utterback, J.M.; Acee, H.J.: Disruptive technologies: an expanded view, International Journal of Innovation Management, 9 (2005), no 1, pp 1-17

7. Sood, A.; Tellis, G.J.: Demystifying disruption: a new model for understanding and predicting disruptive technologies. Marketing Science 30 (2011), no 2, pp 339-354

8. Teece, D. J.: Business Models, Business Strategy and Innovation, Long Range Planning, 43 (2010), no 2-3, pp 172-194

9. Haaker, T.; Bouwman, H.; Janssen, W.; de Reuver, M.: Business model stress testing: A practical approach to test the robustness of a business model, Futures, 89 (2017), pp 14-25
10. Saebi, T.; Lien, L.; Foss, N.J.: What Drives Business Model Adaption? The Impact of Opportunities, Threats and Strategic Orientation, Long Range Planning (2016), doi: 10.1016/j.Irp.2016.06.006

11. Velu, C.: Business model innovation and third-party alliance on the survival of new firms, Technovation, 35 (2015), pp 1-11

12. Cavalcante, S.; Kesting, P.; Ulhøi, J.: Business model dynamics and innovation: (re)establishing the missing linkages, Management Decision, 49 (2011), no 8, pp 1327-1342

13. McGrath, R.: Business models: A discovery driven approach, Long Range Planning, 43 (2010), pp 247-261

14. Chesbrough, H.: Business Model Innovation: Opportunities and Barriers. Long Range Planning, 43 (2010), pp 354-363

15. Lubik, S.; Garnsey, E.: Early Business Model Evolution in Sciencebased Ventures: The Case of Advanced Materials, Long Range Planning, 49 (2016), pp 393-408

16. Sosna, M.; Trevinyo-Rodríguez, R. N.; Velamuri, S. R.: Business model innovation through trial-and-error learning: The Naturhouse case, Long Range Planning, 43 (2010), no 2, pp 383-407

17. Wirtz, B. W.; Schilke, O.; Ullrich, S.: (2010). Strategic development of business models: Implications of the web 2.0 for creating value on the Internet, Long Range Planning, 43 (2010), pp 272-290

18. Amshoff, B.; Dülme, C.; Echterfeld, J.; Gausmeier, J.: Business model patterns for disruptive technologies, International Journal of Innovation Management, 19 (2015), no 3, pp 1540002-1-1540002-22

19. Chesbrough, H.; Rosenbloom, R. S.: The role of the business model in capturing value from innovation: evidence from Xerox Corporation's technology spin-off companies, Industrial and Corporate Change, 11 (2002), no 3, pp 529-555

20. Tripsas, M.; Gavetti, G.: Capabilities, cognition, and inertia: Evidence from digital imaging, Strategic Management Journal, 21 (2000), no 10-11, pp 1147-1161

21. Bohnsack, R.; Pinkse, J.; Kolk, A.: Business models for sustainable technologies: Exploring business model evolution in the case of electric vehicles, Research Policy, 43 (2014), no 2, pp 284-300

22. Rothmann, W.: Wahrnehmung des strategischen Handlungsspielraumes, Wiesbaden: Springer Fachmedien, 2013

23. Sabatier, V.; Craig-Kennard, A.; Mangematin, V.: When technological discontinuities and disruptive business models challenge dominant industry logics: Insights from the drugs industry, Technological Forecasting and Social Change, 79 (2012), no 5, pp 949-962

24. Christensen, C. M.: The Ongoing Process of Building a Theory of Disruption, Journal of Product Innovation Management, 23 (2006), pp 39-55

25. Markides, C.: Disruptive Innovation: In Need of Better Theory, Journal of Product Innovation Management, 23 (2006), no 1, pp 19-25

26. Sandström, C.: A Revised Perspective on Disruptive Innovation: Exploring Value Networks and Business Models, Chalmers, Gothenburg, Sweden, 2010

27. DaSilva, C. M.; Trkman, P.: Business Model: What It Is and What It Is Not, Long Range Planning, 47 (2014), no 6, pp 379-389

28. Tongur, S.; Engwall, M.: The business model dilemma of technology shifts, Technovation, 34 (2014), no 9, pp 525-535 